\title{
Simbologias religiosas e imaginário: reflexões acerca do bestiário dos quatro evangelistas
}

\author{
Religious and imaginary symbols: reflections \\ about the bishop of the four evangelists
}

Luiza Liene Bressan ${ }^{1}$

http://lattes.cnpq.br/6385738721254449

\author{
Ana Caroline Voltolini Fernandes ${ }^{2}$ \\ http://lattes.cnpq.br/0049745805283324
}

\author{
Heloisa Juncklaus Preis Moraes ${ }^{3}$ \\ http://orcid.org/0000-0003-2038-7022 \\ http://lattes.cnpq.br/2708511159840663
}

Enviado em: 06/09/2018

Aceito em: 08/11/2018

\begin{abstract}
Resumo: O objetivo deste estudo é discutir conceitos teóricos que podem convergir ao simbolismo que se manifesta nas imagens dos quatro evangelistas que estão representados na nave central da catedral metropolitana de Porto Alegre, Rio Grande do Sul. O escopo teórico centra-se na teoria do imaginário. Nosso estudo está ancorado na análise das imagens dos apóstolos e, mais especificamente, nos animais pelos quais os mesmos são representados, pois o animal tem um lugar particular no imaginário humano bem como para a narrativa formada em torno das imagens. Assim, vemos esta representação enquanto arte, mas também enquanto constelação de imagens simbólicas que estruturam o imaginário do sagrado. É a partir de uma hermenêutica simbólica das imagens que apresentamos seus sentidos em função do bestiário presente nas representações e instauradoras de sentimento de pertença, onde o imaginário é reservatório e motor.

Palavras-chave: Religiosidade. Evangelistas. Imagens sacras. Simbolismo.
\end{abstract}

Abstract: The objective of this study is to discuss theoretical concepts that can converge to the symbolism that is manifested in the images of the four evangelists that are represented in the central nave of the metropolitan cathedral of Porto Alegre, Rio Grande do Sul. The theoretical scope focuses on the theory of the imaginary. Our study is anchored in the analysis of the images of the apostles and, more specifically, in the animals by which they are represented, for the animal has a particular place in the human imagination as well as for the narrative formed around the images. Thus, we see this representation as art, but also as a constellation of symbolic images that structure the imaginary of the sacred. It is from a symbolic hermeneutics of the images that we present its senses in function of the bestiary present in the representations and instituting a feeling of belonging, where the imaginary is reservoir and motor.

Keywords: Religiosity. Evangelists. Sacred images. Symbolism.

\footnotetext{
${ }^{1}$ Doutoranda do Programa de Pós-Graduação em Ciências da Linguagem da Universidade do Sul de Santa Catarina. Membro do Grupo de Pesquisas do Imaginário e Cotidiano.E-mail: luizalbc@yahoo.com.br

2 Mestranda no Programa de Pós-Graduação em Ciências da Linguagem da Universidade do Sul de Santa Catarina. Membro do Grupo de Pesquisas do Imaginário e Cotidiano. E-mail: anacaroline.voltolini@hotmail.com

3 Doutora. Docente do Programa de Pós-Graduação em Ciências da Linguagem da Universidade do Sul de Santa Catarina. Líder do Grupo de Pesquisas do Imaginário e Cotidiano. E-mail: heloisapreis@hotmail.com
} 


\section{Introdução}

O foco deste estudo são as imagens dos quatro evangelistas: São Mateus, São Marcos, São Lucas e São João, dispostas na nave central da catedral metropolitana Madre de Deus, de Porto Alegre, Rio Grande do Sul, para discutir os sentidos dos simbolismos, aqui religiosos, para uma implicação no vivido. O sentido está não só naquilo que se diz, mas também em algo que se quer dizer, sobre algo que nos quer dizer.

Além das questões voltadas à religiosidade, nosso estudo está ancorado na análise das imagens dos apóstolos e, mais especificamente, nos animais pelos quais os mesmos são representados, pois o animal tem um lugar particular no imaginário humano. Assim, ao ver a representação enquanto arte, mas também enquanto constelação de imagens simbólicas que estruturam o imaginário do sagrado, formando uma narrativa. $O$ espaço da cognição que as expressões simbólicas dos animais ocupam é bastante significado, pois, como nos orienta Ronecker (1997, p.14), "o simbolismo animal reflete não os animais, mas a ideia que o homem tem deles e, talvez, definitivamente, a ideia que tem de si próprio". É a partir de uma hermenêutica simbólica das imagens que apresentamos seus sentidos em função do bestiário presente nas representações, partindo da proposição da Ortiz-Osés (in ARAÚJO; BAPTISTA, 2003, p. 100) de que o sentido, na Hermenêutica, é "uma explicação implicativa do real vivido" ou seja, "há um sentido consentido com cumplicidade" e que motiva a vivência das pessoas.

Sendo o homem um animal simbólico, como nos trouxe Cassirer, a realidade enuncia essa relação simbólica, em relação de co-pertença. "O simbolismo é a expressão humana do sentido do mundo, a linguagem que aponta para além de si mesma, uma vez que participa no sentido do simbolizado" (ORTIZ-OSÉS, in ARAÚJO; BAPTISTA, 2003, p. 101).

\section{A religiosidade como elemento fundante do indivíduo e sociedade}

A caminhada antropológica do humano é cercada de teorizações sobre sua origem, sua natureza e seu fim. Poder-se-ia imaginar que tal característica seria própria das religiões, no entanto, a base da própria filosofia e inclusive da ciência visa, em seu âmago, responder a tais questões. Pode-se, inclusive, verificar que além das diferenças básicas entre o humano e o animal - linguagem, postura ereta, domínio tecnológico, entre outras - a característica que mais o diferencia das outras espécies é sua capacidade de teorizar sobre sua existência, querelar, decidir sobre quais atividades desempenhar ou deixar de desempenhar, organizarse em grupos não só segundo sua espécie, mas principalmente segundo ideias e opiniões.

Os aspectos sociais, culturais, religiosos e familiares contribuem sim para que cada pessoa se conduza de determinada forma ao longo de seu viver, mas não garantem que todas respondam ao mesmo estímulo de forma semelhante. A multiplicidade de religiões existentes é um bom exemplo de tal situação. Cada civilização desenvolveu sua própria compreensão do sagrado e a partir de então toda divergência de opinião sobre algum ângulo da doutrina, muito rapidamente se tornou uma nova religião. Através da possibilidade de dialogar, indivíduos passaram a se reunir de acordo com suas visões de mundo e aspirações espirituais.

Os relatos míticos, suas imagens e simbolismos, tornam-se mediações imaginárias, capazes de aprofundar o sentido das coisas. A linguagem mítica, por sua capacidade representativa, afeto o leitor em todos os seus aspectos: "pela mediação das imagens articuladas no mito, o religioso e a vida moral tomam forma mais atractiva e ganham mais força (VAZ 
in ARAÚJO; BAPTISTA, 2003, p. 413). E continua o autor sobre a força das imagens: "a mente do leitor, através de sentimentos de prazer e de bondade e de pena ou dificuldade, percebe a configuração duma ordem vital a apontar para um fim, e esta torna-se para o leitor um 'símbolo' do bem, ao qual sente que se deve unir'.

Assim, como os estudos de Vaz (in ARAÚJO; BAPTISTA, 2003) sobre a narrativa bíblica em Gênesis, a simbologia religiosa das imagens dos apóstolos extravasa um dever-ser, uma ligação, cristaliza um sentido superior que se consolida na tradição. "A profundidade da linguagem poética do mito não está no que diz ou conta, mas no que intui, insinua, sugere, na convicção inquestionável de que a forma mais nobre de olhar para as coisas é vê-las na divindade e em relação com ela" (VAZ in ARAÚJO; BAPTISTA, 2003, p. 414). As narrativas simbólicas, não só as escritas, fazem esse papel.

Dessa forma, a necessidade de teorizar e encontrar respostas para as questões existenciais de "o que sou, de onde vim, para onde vou" rege o viver humano, especialmente pela sua capacidade imaginativa. Sobre o assunto, Eliade afirma:

É inútil continuar a insistir no valor existencial do conhecimento da origem nas sociedades tradicionais. O comportamento não é exclusivamente arcaico. O desejo de conhecer a origem das coisas caracteriza também a cultura ocidental. O século XVIII e, sobretudo, o século XIX, viram multiplicar-se as investigações não só acerca do Universo, da vida, das espécies ou do homem, mas também acerca da origem da sociedade, da linguagem, da religião e de todas as instituições humanas. Faz-se o possível por conhecer a origem e a história de tudo o que nos rodeia: a origem do sistema solar, bem como a de uma instituição como o casamento ou de um jogo de crianças como o "jogo da macaca" (ELIADE, 1972, p. 68).

Quando as inquietações existenciais se sobressaem na infância, rapidamente os genitores dão alguma explicação reducionista sobre o caso, como por exemplo, a criança ter sido trazida por uma cegonha ou virar uma estrela após o evento morte. São exemplos, também de uma simbolização ancorada em uma narrativa que produz um sentido. Já nos orienta Durand (2002) que a função do imaginário é, pois, eufemização. Durante a adolescência, as escolas evidenciam o posicionamento científico do Big Bang e o Darwinismo, por exemplo. Enfim, durante toda o viver a pessoa é impregnada por várias teorias que tentam explicar suas indagações sobre a origem. E todos sendo apoiados por simbologias.

Pois bem, o fato é que em maior ou menor escala, mesmo não havendo explicações "reais" sobre a essência das coisas, tem-se a tendência de encontrar justificativas para o que quer que seja, pois sem elas o viver seria destituído de qualquer valor. Viktor Frankl, psicanalista que teve possibilidade de estar em um campo de concentração durante a Segunda Guerra Mundial, verificou que os seres humanos têm a tendência de suportar o sofrimento somente se houver um motivo substancial maior que a própria pessoa, como por exemplo, um filho, uma família, enfim, um propósito maior que o próprio sujeito.

É por meio do imaginário que há a possibilidade de se vislumbrar uma gama de significações possíveis. Nada mais é vazio e ordinário, pois ainda que se questione e se alegue a inexistência do real - cuja discussão, alegação de validade ou invalidade são inócuas, dada o constante avanço tecnológico que evidencia a existência de vários aspectos do universo não conhecidos pelo ser humano -, o sentido e as explicações são encontradas e/ou criadas, em razão da natureza simbolizante presente no indivíduo.

Isso porque, compreendendo a origem, o indivíduo passa a compreender o mundo que o cerca, tendo em vista que os atos da vida cotidiana são resquícios ou "sombras" de algo que aconteceu in illo tempore: 
Agora, vamo-nos voltar para os atos humanos — aqueles, naturalmente, que não têm origem no mero automatismo. Seu significado, seu valor, não estão vinculados a seus rudes dados físicos, mas sim à sua propriedade de reproduzir um ato primordial, de repetição de um exemplo mítico. A nutrição não representa uma simples operação fisiológica; ela renova uma comunhão. O casamento e a orgia coletiva são ecos de protótipos míticos; são repetidos porque foram consagrados no começo ("naqueles dias", in illo tempore, ab origine) pelos deuses, pelos ancestrais ou por heróis.

Nos elementos particulares de seu comportamento consciente, o homem "primitivo", arcaico, não reconhece qualquer ato que não tenha sido previamente praticado e vivido por outra pessoa, algum outro ser que não tivesse sido um homem. Tudo o que ele faz já foi feito antes. Sua vida representa a incessante repetição dos gestos iniciados por outros (ELIADE, 1992, p. 25).

$\mathrm{Na}$ vida social há que se destacar a importância das representações coletivas e da dimensão estética, sendo que é o imaginário que desempenha papel fundamental nesta ambiência. As sociedades se estabelecem e subsidiam enquanto comunidades simbólicas, tratase, pois, de uma instituição primordial: as relações simbólicas. O pensamento simbólico e mítico como fundador do laço social cuja cultura seja um conjunto de sistemas simbólicos do qual a religião e as artes fazem parte (SIRONNEAU, 2003). Os símbolos expressam por um sociedade, de forma sensível, permite a consciência coletiva e a comunhão. Sendo que as crenças, os ritos e os objetos venerados devem ser interpretados simbolicamente.

A maciça apatia em relação à busca da origem que caracteriza o século XXI faz com que as pessoas vivam tão somente o profano, o trivial, os quais são passageiros e acabam por não satisfazer a totalidade do ser. A busca incessante e frenética por bens de consumo e emoções efêmeras é a soteriologia da contemporaneidade e não satisfaz o âmago do indivíduo. Interessante notar que Eliade (1979, p. 99) afirmou "que somente através da comparação de fenômenos religiosos semelhantes pode-se chegar simultaneamente à apreensão de sua estrutura geral e de seus significados particulares, específicos". Isso significa dizer que o estudo profundo das religiões e mitos culminam com o conhecimento integral da esfera ontológica necessária para se encontrar "o paraíso perdido" tão buscado pelo ser humano. Sobre o tema, Campbell postulou que

as literaturas grega e latina e a Bíblia costumavam fazer parte da educação de toda gente. Tendo sido suprimidas, toda uma tradição de informações mitológicas do Ocidente se perdeu. Muitas histórias se conservavam, de hábito, na mente das pessoas. Quando a história está em sua mente, você percebe sua relevância para com aquilo que esteja acontecendo em sua vida. Isso dá perspectiva ao que lhe está acontecendo. Com a perda disso, perdemos efetivamente algo, porque não possuímos nada semelhante para pôr no lugar. Esses bocados de informação, provenientes dos tempos antigos, que têm a ver com os temas que sempre deram sustentação à vida humana, que construíram civilizações e enformaram religiões através dos séculos, têm a ver com os profundos problemas interiores, com os profundos mistérios, com os profundos limiares da travessia, e se você não souber o que dizem os sinais ao longo do caminho, terá de produzi-los por sua conta. Mas assim que for apanhado pelo assunto, haverá um tal senso de informação, de uma ou outra dessas tradições, de uma espécie tão profunda, tão rica e vivificadora, que você não abrirá mão dele (CAMPBELL, 1990, p. 4).

Isso explica o engajamento que alguns líderes religiosos têm em professar determinadas crenças, pois possivelmente as informações predicadas em determinada doutrina podem ter lhes dado uma compreensão de mundo que esses mesmos líderes gostariam que os demais tivessem. Um exemplo de tal situação é o próprio cristianismo. Toda a organização social e religiosa ocidental - cuja convivência e simbiose se deu ao longo da história a ponto de não saber se uma existiu sem a outra - fundamentou-se para que o cristianismo fosse levado 
adiante.

Importante destacar que os ensinamentos de Jesus Cristo, figura essencial que caracteriza a doutrina cristã, foi de substancial importância para alguns de seus discípulos, os quais, segundo as escrituras, decidiram por levar adiante os ensinamentos daquele que trouxe informações responsáveis por abalar a ordem vigente da socie-

dade judaica. Nesse sentido, a missão de um apóstolo é de grande importância para o início e desenvolvimento de determinada organização religiosa, pois é através dos registros atribuídos a ele que os ensinamentos de seu mestre poderão ser acessados por outras pessoas, criando-se um imaginário acerca deste símbolo e sua representatividade.

A relevância de estudar o vínculo entre discípulo e mestre é fundamental para compreender o âmago da mensagem religiosa ou filosofia estudada, pois como já anteriormente mencionado, a compreensão de cada pessoa é moldada pelo seu meio, suas experiências, crenças e verdades arraigadas paulatinamente durante toda sua existência. Considerando que boa parte dos mestres que tiveram suas existências propagadas não deixaram registros escritos, como por exemplo, Jesus Cristo e Siddhartha Gautama, é imperioso o estudo dos símbolos, de seus discursos e objetos de adoração que, por sua força simbólica, instituem o imaginário coletivo de um grupo.

\section{Apostolado Cristão}

Primeiramente se faz importante esclarecer que é no Novo Testamento em que há o registro do nascimento e trajetória de Jesus Cristo. Embora a própria existência e validade dos escritos bíblicos sobre a vida do referido mestre cristão por vezes seja questionada pela arqueologia e paleontologia, o objetivo deste artigo não é indicar a autenticidade ou não do mencionados registros, mas tão somente apresentar os principais aspectos da missão apostólica de um cristão.

Da mesma forma, é importante esclarecer a conceituação do termo apóstolo, pois ainda que atualmente o termo tenha conotação puramente religiosa, a referida palavra também foi utilizada em um passado remoto para representar outras situações em contextos não sectários.

A palavra "apóstolo" é de origem grega e significa, em seu sentido mais básico, "enviado". Ocorre que o uso do termo já era feito antes ser utilizado no Novo Testamento e era normalmente empregado no contexto de expedições marítimas, especialmente militares. Posteriormente, passou a ser empregado ao grupo de expedicionários que povoavam uma localidade e, posteriormente, ao comandante daquele grupo (LOPES, 2014, p. 23).

Já no Novo Testamento, foi o próprio Jesus quem utilizou o termo no evangelho de Lucas para designar doze homens, dentre seus discípulos, como seus apóstolos:

Num daqueles dias, Jesus saiu para monte a fim de orar, e passou a noite orando a Deus. Ao amanhecer chamou seus discípulos e escolheu doze deles, a quem também designou de apóstolos. Simão, a quem deu o nome de Pedro; seu irmão André; Tiago; João; Filipe; Bartolomeu; Mateus; Tomé; Tiago, filho de Alfeu; Simão, chamado zelote; Judas, filho de Tiago; e Judas Iscariotes, que veio a ser o traidor (LUCAS, 2013, p. 1678).

Para Lopes (2014, p. 27), Jesus resgatou o termo "apóstolo" do Antigo Testamento, pois quando um reino era conquistado na antiguidade, os reis de Israel mandavam seus representantes legais para o cumprimento de uma missão. Dessa forma, esses representantes atuariam na terra conquistada como se fossem o próprio rei: 
Há alguns episódios no Antigo Testamento que mostram que a representação autoriz̧ada era uma instituição conhecida no Antigo Oriente e entre os judeus. [...]

O episódio da invasão de Judá pelo rei assírio Senaqueribe, que enviou como seu representante ao rei Ezequias o general Rabsaqué, com cartas e ameaças em nome do rei (Is 36.1-10), é um exemplo. (LOPES, 2014, p. 27).

Nesse mesmo sentido seria a atribuição dos apóstolos, pois quando Jesus os nomeou, estes passaram a ter a representação autorizada conferida pelo próprio mestre:

A familiaridade de Jesus com este conceito se reflete em algumas das instruções que eles passou aos doze. Ele lhes disse que aqueles que os recebessem estariam recebendo a ele próprio [...]; quem os escutasse estariam escutando ao próprio Jesus e quem os rejeitasse rejeitariam a ele mesmo (Lc 10.16). Jesus lhes deu poderes para fazerem as mesmas coisas que ele fazia, como expelir demônios, curar doentes e pregar a chegada do Reino de Deus [...]. (LOPES, 2014, p. 28).

Por essa razão, a escolha dos apóstolos por Jesus teria o condão de indicar os indivíduos responsáveis por dar continuidade à obra que ele havia iniciado, chancelando-os como representantes autorizados. Sobre tais atribuições, os próprios registros bíblicos indicam as incumbências repassadas por Jesus aos seus apóstolos (Mc 3.14; 6.7; Lc 9.2):

Escolheu doze, designando-os apóstolos, para que estivessem com ele, os enviasse a pregar e tivessem autoridade para expulsar demônios. Estes são os doze que ele escolheu: Simão, a quem deu o nome de Pedro; seu irmão André; Tiago; João; Filipe; Bartolomeu; Mateus; Tomé; Tiago, filho de Alfeu; Simão, chamado zelote; Judas, filho de Tiago; e Judas Iscariotes, que veio a ser o traidor. [...]

Fiquem atentos, pois vocês serão entregues aos tribunais e serão açoitados nas sinagogas. Por minha causa vocês serão levados à presença de governantes e reis, como testemunho a eles. E é necessário que antes o evangelho seja pregado a todas as nações. Sempre que forem presos e lavados a julgamento, não fiquem preocupados com o que vão dizer. Digam tão somente o que for dado a vocês naquela hora, pois não serão vocês que estarão falando, mas o Espírito Santo. $[\ldots .$.

Então Jesus passou a percorrer os povoados, ensinando. Chamando os doze para junto de si, enviou-os de dois em dois e deu-lhes autoridade sobre os espíritos imundos. Estas foram as suas instruções: não levem nada pelo caminho, a não ser um bordão. Não levem pão, nem saco de viagem, nem dinheiro em seus cintos; calcem sandálias, mas não levem túnica extra; sempre que entrarem numa casa, fiquem ali até partirem; e, se algum povoado não os receber nem os ouvir, sacudam a poeira dos seus és quando saírem de lá, como testemunho contra eles (MARCOS, 2013, p. 1637).

Ainda doze pessoas tenham sido nomeadas a fim de dar continuidade à mensagem predicada por Jesus Cristo, a vida deste - que por si só representa grande parte dos ensinamentos cristãos e é a essência do cristianismo - foi registrada nos livros de Mateus, Marcos, Lucas e João. Se a intenção de Jesus era que seus ensinamentos tivessem continuidade e fossem predicados não só para os judeus, mas em todo o mundo, nada melhor que sua vida e mensagem fossem registradas através da palavra escrita.

Dessa forma, os quatro primeiros livros do Novo Testamento que registram a vida de Jesus são chamados de "evangelhos" ou "boas novas", os quais são atribuídos a Mateus, Marcos, Lucas e João.

Para Eliade (1993, p. 87), o cânone cristão só se deu em razão dos vinte e sete escritos do Novo Testamento, que seriam os quatro Evangelhos (Marcos, Mateus, Lucas e João), 
os quatro Atos dos Apóstolos, as epístolas dos Apóstolos e o Apocalipse, este último atribuído a João. Sobre os Evangelhos, Eliade e Couliano afirmam:

Quanto aos Evangelhos, são um produto tardio, fundado em várias tradições. Os três primeiros (Mateus, Marcos, Lucas) são chamados sinópticos devido às semelhanças que existem entre eles e que fazem com que se possa colocá-los em três colunas paralelas. O Evangelho S. Marcos, redigido sensivelmente em 70, é o mais antigo. Os outros dois (cerca do ano 80) seguem o de Marcos e uma segunda fonte chamada Q. Escrito pouco antes de 100, o Evangelho dito de João é mais esotérico e incorpora elementos platónicos muito marcados, sobretudo na assimilação de Cristo ao Logo de Deus que é o plano divino da arquitetura do mundo. Por outro lado, o Evangelho de João expressa uma opinião muito negativa em relação ao mundo social (chamado este mundo), dominado pelo diabo, que aparece mais como adversário do que como servidor de Deus. Estas concepções foram muito frequentemente comparadas ao gnosticismo e à literatura essénia de Qumran, o que só prova que certos escritos do Novo Testamento são demasiadamente vagos para poderem tolerar as teorias mais diversas (ELIADE; COULIANO; 1993, p. 87-88).

Interessante observar que cristianismo primitivo é marcado por dissensões não só com o judaísmo como normalmente se costuma pensar, mas também e, talvez principalmente com o gnosticismo, pois este último, sobretudo ao que concerne o Evangelho de João mais esotérico, como afirmou Eliade no excerto acima - defenderia a existência de um conhecimento inacessível aos simples fiéis cristãos.

Essa dissensão entre gnosticismo e cristianismo foi fortemente acentuada pelo patrístico Irineu de Lião, o qual, em sua obra Contra as Heresias, defendeu fortemente a supremacia dos evangelhos escritos por Mateus, Marcos, Lucas e João, afirmando que toda a verdade estaria descrita nos referidos evangelhos e que não haveria, como os gnósticos predicavam, um conhecimento esotérico não revelado nas escrituras e que só poucos teriam acesso.

Interessante observar que é nessa mesma obra do patrístico bispo Irineu de Lião que ocorre a primeira associação entre os quatro evangelistas - Mateus, Marcos, Lucas e João com elementos simbólicos. Isso porque a arte sacra presente em muitas igrejas católicas costumam evidenciar esculturas dos já mencionados evangelistas com os símbolos de animais e de um homem. As referidas esculturas associam o evangelista Marcos ao leão, Lucas ao touro, São João à águia e Mateus à figura de um homem.

Dessa forma, para melhor compreender a associação de tais evangelistas com os referidos símbolos, importante indicar o texto primal em que a correlação entre eles foi feita:

[...] os evangelhos não são, nem mais nem menos, do que estes quatro. Com efeito, são quatro as regiões do mundo em que vivemos, quatro são os ventos principais e visto que a Igreja já é espalhada por toda a terra e como tem por fundamento e coluna o Evangelho e o Espírito da vida, assim são quatro as colunas que espalham por toda parte a incorruptibilidade e dão vida aos homens. Por isso é evidente que o Verbo, Artífice de todas as coisas, que está sentado acima dos querubins e mantém unidas todas as coisas, quando se manifestou aos homens, nos deu um Evangelho quadriforme, sustentado por um único Espírito. Por isso Davi, ao invocar a sua vinda, diz: "Tu que te assentas acima dos querubins, aparece". Ora, os querubins têm quatro aspectos, e suas figuras são a imagem da atividade do Filho de Deus. Ele diz: "O primeiro animal é semelhante a leão, caracterizando o poder, a supremacia e a realeza; o segundo é semelhante a novilho, manifestando a sua destinação ao sacrifício, ao sacerdócio; "O terceiro tem rosto semelhante a homem", o que lembra claramente sua vinda em forma humana; e "o quarto se assemelha-se à águia" que voa, sinal do dom do Espírito que sopra sobre a Igreja. Os evangelhos, portanto, correspondem a estes animais, acima dos quais está sentado Jesus Cristo. Um conta a geração preeminente, poderosa e gloriosa que tem do Pai, com estas palavras: "no 
princípio era o Verbo e o Verbo estava com Deus e o Verbo era Deus; e: Tudo foi feito por meio dele e sem ele nada foi feito. É por isso que este Evangelho está cheio de pensamentos sublimes; pois este é o seu aspecto. O Evangelho segundo Lucas, portador de caráter sacerdotal, começa com o sacerdote Zacarias que oferecem a Deus os sacrifício do incenso, porque já estava pronto o vitelo gordo que devia ser imolado por causa da volta do filho menor. Mateus, por sua vez, narra a sua geração humana, dizendo: "Livro da origem de Jesus Cristo, filho de Davi, filho de Abraão". E em seguida: "A origem de Jesus Cristo foi assim". É portanto, o Evangelho da humanidade de Cristo, por isso Jesus é constantemente apresentado como homem humilde e manso. Marcos, por sua vez, inicia pelo Espírito Profético que do alto investe o homem: "Princípio do Evangelho; conforme está escrito no profeta Isaías ..., dando uma imagem alada do Evangelho. Por isso exprime-se de maneira concisa e rápida: é o estilo profético. [...] Em suma, da forma como se apresenta a atividade do Filho de Deus assim é o aspecto dos animais e igual ao aspecto dos animais é a característica do Evangelho: quadriforme os animais, quadriforme o Evangelho, quadriforme a atividade do Senhor. (IRENEU, p. 283, 1995)

Nesse excerto, Irineu de Lião apresentou a principal correlação entre o simbolismo inerente aos evangelistas, afirmando que as características essenciais dos animais ou no caso do homem seriam as mesmas características da atividade do filho de deus e dos próprios evangelhos. No caso do leão, o aspecto de poder e supremacia da atividade do filho do homem; o novilho, a destinação deste ao sacrifício e sacerdócio; o rosto humano, à sua estrutura antropomórfica humana; e por fim, a águia, que remonta à natureza diáfana do espírito.

É inegável a importância do simbolismo para o homo sapiens, pois nas palavras de Eliade, as imagens e os símbolos constituem-se para o homem aberturas sobre um mundo de significações mais abrangentes do que aquele onde ele vive. Os objetos do mundo e os atos humanos não teriam valor por si só, eles adquirem valor quando participam de uma realidade que os transcendem (ELIADE, 1952, p. 13).

\section{Os Quatro Evangelistas e a Simbologia Animal}

Este estudo teve origem em uma visita feita pelas pesquisadoras à catedral de Porto Alegre, Rio Grande do Sul. Durante a visita, a iconografia dos quatro evangelistas, guardiões do altar-mor da catedral, despertaram a motivação dessa discussão, já engendradas por outras questões do imaginário do sagrado.

A partir de reflexões iniciais, as imagens foram fotografadas para que pudéssemos realizar essa contemplação, cujo foco está na análise dos símbolos que reforçam a representação imaginal dos quatro evangelista e formam uma narrativa, através da arte, e presente no imaginário católico.

Segundo Mardones (2006), o simbolismo manifesto em iconografias tem uma maneira muito particular de envolver as pessoas. Ele sensibiliza, toca e desperta o sublime, o infinito que adormece no íntimo do ser humano e o remete para fora dele mesmo, em expressões de admiração e contemplação, pela experiência da transcendentalidade.

Nas imagens dos quatro evangelistas dispostas na nave central da catedral de Porto Alegre, os apóstolos estão representados com seus símbolos que são o anjo para São Mateus; o leão para representar São Marcos; o boi simbolizando São Lucas e, finalmente, a águia, símbolo de São João.

Começamos a análise a partir da imagem de São Mateus, o primeiro dos evangelistas. 


\section{Imagem 1- São Mateus}

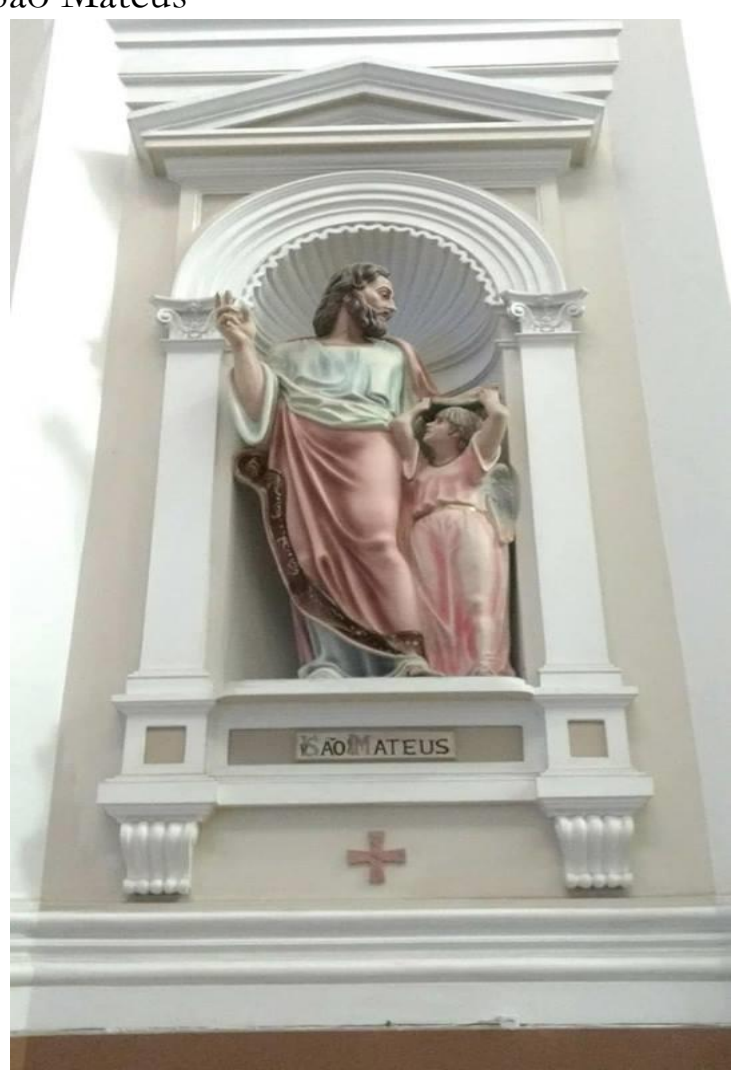

Fonte: São Mateus, catedral de Porto Alegre. Arquivo das autoras, 2017.

Para Harrington (1985, p.464) Mateus, conforme a tradição da igreja primitiva, é um dos doze escolhidos.

A tradição unânime da igreja primitiva é de que Mateus, um dos Doze, foi o primeiro dos quatro evangelistas a escrever um evangelho, e que ele escreveu em aramaico. Todavia, o evangelho de Mateus, como nos chegou às mãos no Novo Testamento, foi escrito em grego; não é uma tradução. A relação entre o tradicional escrito aramaico e o evangelho posterior é obscura. Mateus pode ter sido o autor da obra aramaica; é-nos impossível dar o nome do autor do evangelho grego. Por questão de conveniência ele continua a ser, em nossas referências, o evangelho de Mateus.

O simbolismo em imagens religiosas evoca, segundo Yates (2007 p. 90), "algo ausente e impossível de ser percebido, pois seu significado é inacessível e transcendente”. Sua imagem funciona como um auxílio à memória, "pois muitos acontecimentos podem ser relembrados através de algumas poucas imagens simbólicas que podem oferecer informações mais exatas, mais sensíveis e de longo alcance".

Assim, o evangelista Mateus é representado pela figura de um homem acompanhado por um menino alado (anjo) porque seu evangelho inicia com a genealogia de Jesus, dando enfoque a sua origem e descendência humana, mais que sua divindade, marcado pelo seu nascimento e por ter criado o homem à sua imagem e semelhança.

Com vestes rosáceas e verde, cabelos e barba escuros, a imagem de Mateus sugere sabedoria de um homem maduro que ouve o menino alado e que o olha atentamente, trazendo as escrituras sagradas sobre a cabeça. O livro sobre a cabeça é um simbolismo que aponta orientações sobre a vivência e a prática do cristianismo, pois a interpretação, implica 
a descoberta dos valores simbólicos, trazendo à luz seus nexos históricos. O conteúdo de uma obra pode revelar "[...] a atitude básica de uma nação, de um período, classe social, crença religiosa ou filosófica qualificados por uma personalidade e condensados numa obra" (PANOFSKY, 2007, p. 52).

A imagem representa, assim, a crença religiosa e a atitude do evangelista de seguir as orientações contidas no texto sagrado, indicado pelo menino-alado com norte para a construção do simbolismo católico-cristão.

\section{Imagem 02- São Marcos}

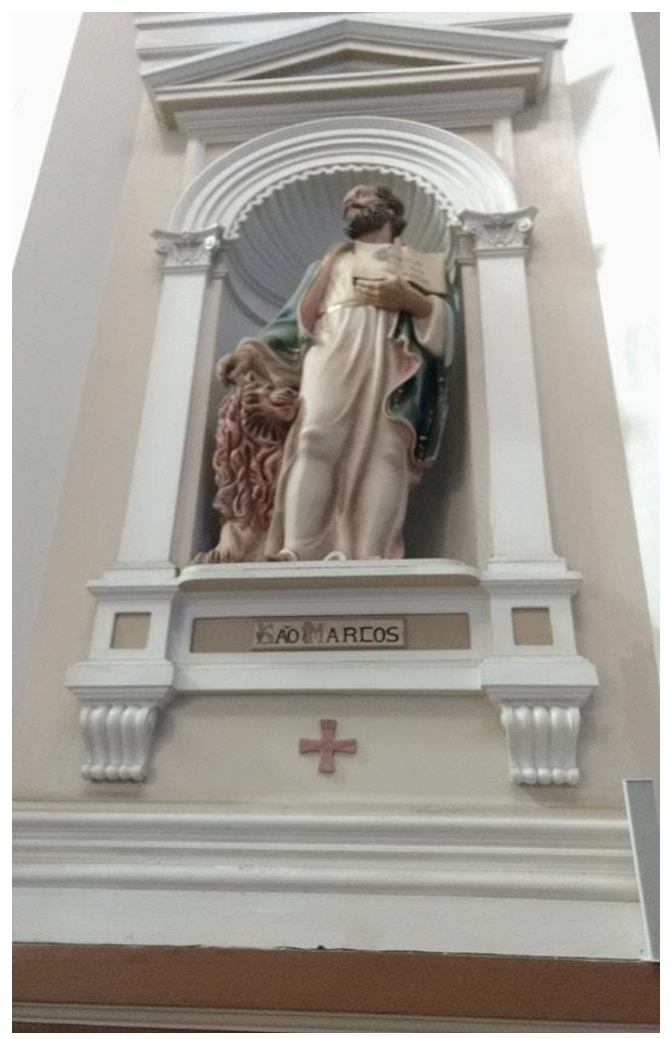

Fonte: São Marcos, catedral de Porto Alegre. Arquivo das autoras, 2017.

O autor do evangelho sinótico mais primitivo é identificado pelo nome de Marcos que tem inúmeras citações nos Evangelhos e no livro dos Atos dos Apóstolos. Evangelista São Marcos é representado pela figura de um leão, porque começou a narração de seu evangelho com a pregação de João Batista no deserto, onde havia animais selvagens, entre eles o leão, símbolo de força e poder de Deus e de sua Palavra.

A imagem apresenta um homem adulto, com vestes brancas e a sobreposição de um manto azul. Ao lado esquerdo aparece a cabeça do leão sobre a qual está a mão do apóstolo. $\mathrm{Na}$ mão direita, alinhada à altura do coração, segura as escrituras sagradas, norte de seu apostolado.

Conforme os estudos de Sganzerla (2013, p. 60):

São Marcos é representado pela figura de um leão porque inicia a narração de seu Evangelho com a pregação de João Batista no deserto, onde havia animais selvagens. De acordo com o profeta (Amós 3,8), podemos dizer que a voz do leão simboliza a voz dos profetas que denunciam a violação do plano de Deus. Portanto, João Batista é o profeta que denuncia a injustiça e aponta para a novidade de Jesus. Ora, o leão vivia no deserto, e a pregação de João Batista 
foi como um rugido de leão. Ele quer mostrar Cristo como soberano, como Rei. E o leão é o rei dos animais. É também a expressão da força. No livro de Apocalipse Jesus é chamado de Leão de Judá, (Apocalipse 5.1-5). A ressurreição de Jesus mostra seu poder sobre seus inimigos. Por isso Jesus é associado ao leão na sua dimensão da força, realeza, poder, autoridade do Filho de Deus.

Neste sentido, a imagem do evangelista Marcos reverbera a força da fé católico-cristã. A Jesus é atribuída a força e a liderança do leão, pois ele é o sol inferior, uma representação 'teriomórfica', (na teoria do imaginário de Durand) do princípio masculino que representa a natureza "ctônica" (relativo à terra), o aspecto terreno do símbolo do rei e do pai. Encontra-se, ainda, associado à concupiscência e ao orgulho, além de ser um animal combativo mas que pode sugerir impulsos agressivos saudáveis (CIRLOT,1984).

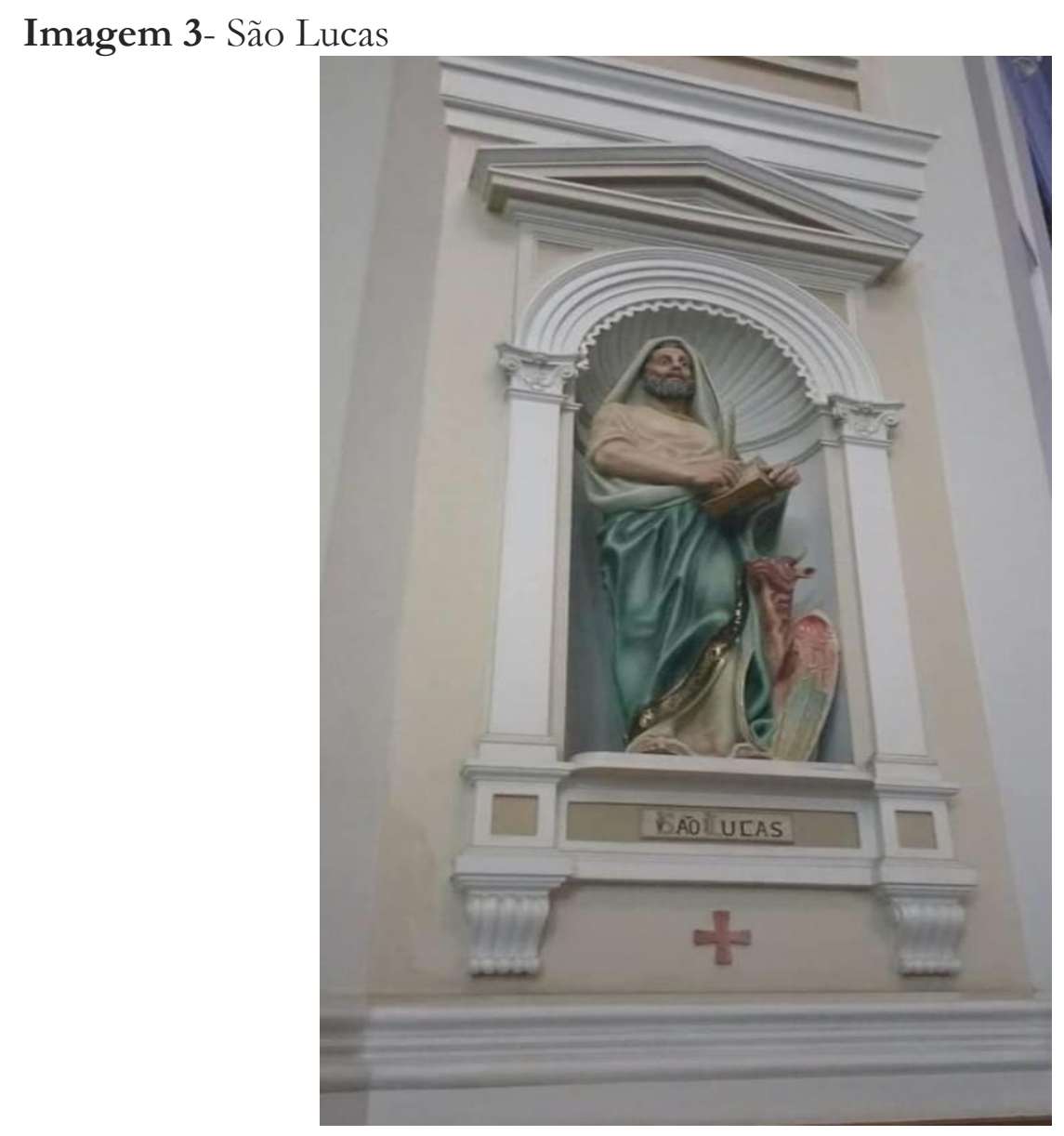

Fonte: São Lucas, catedral de Porto Alegre. Arquivo das autoras, 2017.

O terceiro dos evangelista tem como símbolo de representação a cabeça de um touro. Com vestimenta branca e com um manto azul sobreposto, inclusive cobrindo a cabeça, Lucas é representado nesta imagem com homem de cabelos e barba apresentando traços grisalhos, o que sugere sinal de maturidade. Na mão esquerda segura a escritura e na mão direita, uma pena, como se estivesse fazendo anotações. À sua esquerda uma cabeça de um boi ou touro alado, com a cabeça voltada também para a esquerda, que representa força, serviço e paciência. São Lucas é simbolizado pelo touro porque começou a narração de seu evangelho no templo, local onde animais eram imolados como oferta a Deus. Jesus 
substituiu este tipo de sacrifício e se ofertou a si mesmo a Deus, como ato máximo para redimir o seu povo e oferecer um amor incondicional ao Ser supremo.

Entende-se, neste estudo, a importância da simbologia animal associada às práticas religiosas, pois são inerentes às forças que se constituem para combater as imagens conectadas ao mal. A simbologia do touro que acompanha Lucas pode expressar, também, a passagem entre céu e terra e, ainda, o sacrifício, a abnegação e a castidade.

\section{Imagem 4- São João}

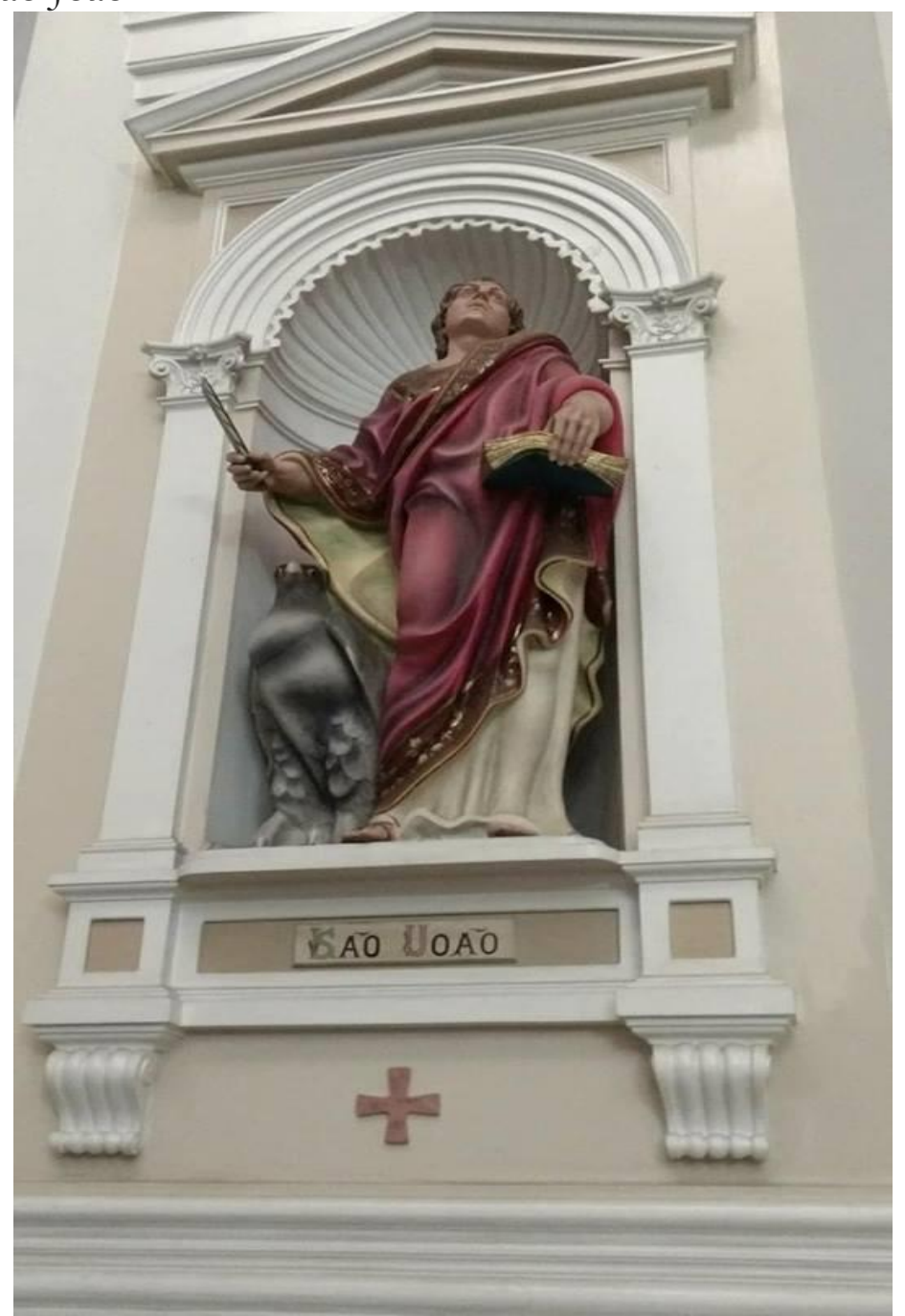

Fonte: São João, catedral de Porto Alegre. Arquivo das autoras, 2017.

O evangelista João é representado pela águia, símbolo de liberdade e força por causa do elevado estilo de seu Evangelho, que ressalta a Divindade e o Mistério do Filho de Deus. Cristo como força e libertação. Sua imagem, em contraste com os três evangelistas já apresentados, é jovial, cabelos mais claros, sem barba. As vestes refletem essa jovialidade, pois sobrepõe-se à túnica branca um manto de cor rubra. Em sua mão esquerda segura o livro sagrado, enquanto à direita empunha a pena. Seu olhar contempla a infinitude do espaço, tendo a águia à esquerda de seus pés.

A águia, símbolo solar por excelência, está ligada à contemplação e à realeza e, ao figurar ao lado do apóstolo João, transcende a experiência de viver e elevar o espírito. A bíblia 
sagrada caracteriza João como o apóstolo escolhido por Jesus para consolar sua mãe, conforme relato do próprio evangelista:

E junto à cruz estavam a mãe de Jesus, e a irmã dela, e Maria, mulher de Clopas, e Maria Madalena. Vendo Jesus sua mãe e junto a ela o discípulo amado, disse: Mulher, eis aí teu filho. Depois, disse ao discípulo: Eis aí tua mãe. Dessa hora em diante, o discípulo a tomou para casa (JOÃO, 19:25-27). (Grifos nossos).

É o apóstolo ‘amado’ que cuidará da mãe e eleva João à categoria de irmão, ao nomeálo filho de Maria. João expressa um desejo muito grande de anunciar Cristo Jesus glorificado à comunidade. Seu Evangelho é um escrito de fé, marcado pelo caminho daquele que fez a experiência profunda do evento Jesus. João pôde penetrar em profundidade o sentido e a motivação da ação de Jesus. Esforça-se por expressá-lo numa linguagem adaptada a seu tempo. Tal incumbência revela a capacidade intelectual do discípulo, o que justifica a águia como simbologia a expressá-lo. Ronecker (1997, p.102) afirma que "a simbólica cristã estabelecia um paralelo com Deus, que considera seus filhos os que creem nele, e rejeita os outros". Assim, a missão de João era propagar as ideias de Jesus e, para tanto, a águia expressaria a nobreza de sua pregação, associando-se à capacidade de autorregenerar-se constantemente, advindo dessa simbologia a eternidade do espírito. Também "assinalemos que a mística da Idade Média muitas vezes insistiu no tema da águia para evocar a visão divina: comparava a oração às asas da águia elevando-se para a luz" (RONECKER, 1997, p.103). Por esse viés é possível compreender a magnitude do evangelista João e o porquê de seu símbolo ser a águia.

\section{Considerações Finais}

O espaço da catedral metropolitana de Porto Alegre nos envolveu e nos remeteu a um universo simbólico, envolvidas que estávamos/estamos pelos estudos do imaginário e, principalmente, pela simbologia das imagens sacras ali representadas. As expressões estéticas revestidas de conteúdos nos fez fotografar as imagens dos quatro evangelistas, dispostos na nave central da catedral para reconstruir o significado simbólico a partir do estudo dos animais que acompanham as já mencionadas imagens.

A representação simbólica, segundo Mardones (2006), constitui-se num veículo privilegiado de transmissão e legitimação cultural dos sentimentos e valores coletivos de identidade passados e transmitidos entre uma geração e outra. Ainda, conforme os estudos de Mardones (2006), o simbolismo manifesto em imagens do sagrado tem uma maneira muito particular de envolver as pessoas. Ele sensibiliza, toca e desperta o sublime, o infinito que adormece no íntimo do ser humano e o remete para fora dele mesmo, em expressões de admiração e contemplação, pela experiência da transcendentalidade. A experiência dessa transcendentalidade simbólica que envolveu as pesquisadoras resultou no estudo aqui realizado, entendendo os símbolos como importantes "estratégias" de ligação afetiva entre as pessoas e as narrativas com as quais se identificam.

\section{Referências}

ARAÚJO, Alberto Filipe; BAPTISTA, Fernando Paulo. Variações sobre o Imaginário: domínios, teorizações, práticas hermenêuticas. Lisboa: Instituto Piaget, 2003.

CAMPBELL, Joseph. O poder do mito. São Paulo: Palas Athena, 1990. 
CIRLOT, Juan-Eduardo. Dicionário dos Símbolos. São Paulo: Editora Moraes, 1984.

DURAND, Gilbert. Estruturas Antropológicas do Imaginário. São Paulo: Martins Fontes, 2002.

ELIADE, Mircea; COULIANO, Ioan P. Dicionário das religiões. Tradução de Pedro Moreira Araújo. Lisboa: Publicações Dom Quixote, 1993.

ELIADE, Mircea. Mito e realidade. São Paulo: Perspectiva, 1972.

. Origens: história e sentido na religião. Lisboa: Edições 70, 1969.

. O Mito do eterno retorno. São Paulo: Mercuryo: 1992.

Imagens e Símbolos. São Paulo: Arcádia, 1952.

HARRINGTON, Wilfrid John. Chave para a Bíblia: a revelação: a promessa: a realização. Paulus: São Paulo, 1985.

IRENEU. Contra as Heresias. Coleção Patrística. 2. ed. São. Paulo: Paulus, 1995.

LOPES, Augustus Nicodemus. Apóstolos: a verdade bíblica sobre o apostolado. São José dos Campos: Fiel, 2014.

LUCAS. Português. In: Bíblia de estudo arqueológica. Tradução de Claiton André Kunz et al. São Paulo: Vida, 2013, p. 1665-1717.

MARCOS. Português. In: Bíblia de estudo arqueológica. Tradução de Claiton André Kunz et al. São Paulo: Vida, 2013, p. 1621-1660.

MARDONES, José Maria. A vida do símbolo: a dimensão simbólica da religião. São Paulo: Paulinas, 2006.

MORAES, Heloisa Juncklaus Preis; BRESSAN, Luiza Liene. Imaginário e religiosidade na obra "Operários de Primeira Hora" de Valdemar Mazzurana e o regime noturno das imagens. Revell, Revista de Estudos Literários da UEMS, v. 2, n. Extra 13, p. 42-58. 2016. Disponível em https:/ / dialnet.unirioja.es/servlet/articulo?codigo $=5915450$

PANOFSKY, Erwin. Significado nas artes visuais. São Paulo: Perspectiva, 2007.

RONECKER, Jean-Paul. O simbolismo animal. São Paulo, Paulus, 1997.

SGANZERLA, Zenilde. Os vitrais da capela São José do Unilasalle de Canoas-RS: Espaço de memória simbólico-religiosa e lassalista. Dissertação de Mestrado apresentada ao Programa de Pós-Graduação em Memória Social e Bens Culturais do Centro Universitário La Salle - UNILASALLE, Canoas, 2013. Disponível em: https://unilasalle.edu.br/public/media/4/files/Mem $\%$ C3\%B3ria $\% 20$ Social $\% 20 \mathrm{e} \% 20 \mathrm{Bens} \% 20 \mathrm{Cultu}$ rais/resumos_dissertacoes_memoria_2014.pdf. Acesso em 12 de julho de 2018.

YATES, A. Frances. A Arte da Memória. Campinas: Editora da Unicamp, 2007. 